\title{
Clocks in grandfather's rocks
}

\section{G.Y. Craig}

The Abyss of Time: Changing Conceptions of the Earth's Antiquity after the Sixteenth Century. By Claude C. Albritton Jr. Pp.251. ISBN 0-87735-341-7. (Freeman, Cooper: 1980.) \$12.75 US only.

THE essence of this story is quite dramatic. The calculated age of the Earth has increased from a little less than 6,000 years to more than 4,500 million years in the last three centuries. The Earth, of course, has remained untouched by this spectacular revolution apart from the addition of these few hundred years. What has changed has been the consensus of opinion by philosophers, theologians, physicists, geologists and evolutionists as to how old the Earth actually is; and it is salutary to be reminded by younger colleagues that estimates of the age of the Earth have doubled even since I was a student in the 1940s. Most fortunately this precipitous rate of ageing seems to have stopped.

The two main ways of looking at the passage of time in geology are not dissimilar from the ways in which we recall our own lives. Events can be put in a rough sequence and then, often with difficulty, slotted into the calendar ("Remember that

\section{IMAGE \\ UNAVAILABLE FOR COPYRIGHT REASONS}

William Thomson, Baron Kelvin (1824-1907). Detail from a cartoon in Vanity Fair.

summer when we went to Brittany and Aunt Doris got ... Now what year was that?'"). And so it is with rocks. Geologists during the nineteenth century pieced together a sequence of geological events which enabled them to construct a relative time scale. Concurrently various attempts were made to establish when these events occurred and especially how old the Earth might be. Such calculations involved rates of erosion and deposition, the rate at which salt is being added to an already salt sea and the rate at which the Earth appeared to be cooling.
The discovery of radioactivity at the end of the last century led to increasingly precise radiometric dating of those rocks containing suitable isotopes; and the two scales, relative and radiometric, can now be correlated to provide a chronological scale of historical geology. This scale is still being extended and refined. Metamorphic rocks in Greenland, for example, have recently been dated at 3,750 million years, the oldest rocks so far discovered.

Dr Albritton's account arose out of a series of lectures given to students and staff at various academic institutions in the United States. The slim, at tractively bound text follows the traditional and by now well-worn path through the maze of geological time by examining the contributions of its protagonists. Leavened by portraits and anecdotes, it is easily read and clearly reveals the influence of religion, conceit, catastrophe, fanaticism, feuds, ignorance, intuition, rocks and radioactivity on the evolution of the concept of geological time.

In spite of jazzy chapter headings Malta's cradle; Solids within solids; $\mathrm{Mr}$ Hook(e); A sacred theory of the earth; Telliamed's story; The epochs of nature; View from the brink; Father William; The four-dimensional jigsaw puzzle; A question of tempo; A plenitude of events; The great tree of life; Kelvin; A numbers game; Radiometric dating; World enough and time - the leading actors are readily unmasked. For the reader who does not care to play this game, the protagonists turn out to be Steno; Hooke; Burnet; De Maillet; Hutton; Smith; Werner and other early stratigraphers such as Sedgwick and Murchison; catastrophists and uniformitarians (I've now broken a New Year resolution not to use that word!) especially Cuvier and Lyell; observers of volcanoes and glaciers (Scrope and Agassiz); Darwin; and lastly late-nineteenth and twentieth century scientists. Pleasingly, the book includes an appraisal of Arthur Holmes' brilliant contributions to the construction of a geological time-scale. The last chapter contains a typical student-textbook analogy: by compressing the major events of the Earth into 365 days, primates appear on Christmas Day and Homo sapiens arrives a mere hour before the dawn of the New Year. Dr Albritton is obliged to devote part of this chapter to a rebuttal of creationist dogma, now so common in parts of the States. Such concern is understandable for he teaches in Texas where fundamentalist views are not unknown.

Yet somehow the excitement of what should be a gripping story is not there. In one form or another it has all been done before, albeit with the historical anecdotes cut to a minimum. Last year two long articles by John MacPhee in, of all places, The New Yorker, conveyed a similar
SCIENTIFIC
BOOKSHOP

H.K. LEWIS can supply works in all branches of Pure and Applied Science. Catalogues on request. Please state interests.

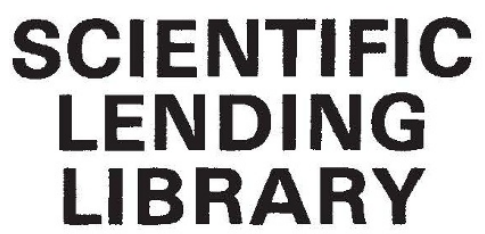

Annual Subscription from $\mathbf{f 7 . 5 0}$

(Available in U.K. only)

Reduced rates for multiple subscriptions.

Prospectus post free on request.

Quarterly List of New Books and new. editions added to the Library sent post free to subscribers regularly.

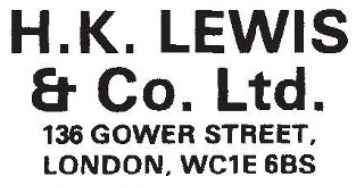

elephone: 01-387 4282

Telegrams: "Publicavit,

ondon, WC1E 6BS."

Circle No.19 on Reader Enquiry Card.

Bring Your Library Up-to-Date With This ANS Edition ... Nuclear Energy in Germany

Winnacker/Wirtz

\section{$6 \times 9$ hardbound edition $\$ 37.00$}

American Nuclear Society 555 North Kensington Avenue La Grange Park, IL 60525 USA

Please take my order for books

Payment in full enclosed. Bill me and I accept postage and handling charges.

Name

Org.

Street

City

State Zip 
message but in a more entertaining style, perhaps because his serious but flowing story was laced with irrelevant cartoons and adverts including fast cars, whisky, cameras, jewellery and beautiful women, but more probably because he linked history with current field-work in different parts of the States.

IMAGE
UNAVAILABLE
FOR
COPYRIGHT
REASONS

James Ussher, Bishop of Armagh - calculated the date of creation as $4004 \mathrm{BC}$.

So here I am, vaguely dissatisfied with a perfectly adequate book simply because of a feeling of déja vu. How can one be constructive? More might have been made of Archbishop Ussher (1581-1656) and his method of calculating the date of creation $(4004 \mathrm{BC})$ and such subsequent events as the grounding of the Ark on Mount Ararat on May 5, 1491 BC (a Wednesday!). His chronology was incorporated in the most widely read book of the day - the King James VI bible - and so had an undue influence in Protestant countries. Many of the subsequent philosophical and scientific investigations described in the Abyss of Time were carried out in the shadow of Ussher's precise chronology. Astronomical calculations and coral clocks are not referred to but they show that the Earth is now rotating more slowly than it did during the Devonian when a year was all of 399 days. Above all, data from meteorites and Moon rocks reveal fascinating events earlier than any now preserved on Earth and provide independent factual evidence of the great antiquity of our Solar System and planet. They could have been the subject of a separate chapter.

And what of the future? The abyss is just as much in front of us as behind. The Earth is steadily losing its heat. As it continues to cool the lithospheric plates will thicken and stop moving: eventually there will be no more volcanic activity and no more earthquakes, but the land will continue to be eroded seawards, there to remain because uplift will no longer occur. The rock cycle will finally have come to an end: but there is perhaps consolation in the fact that the Sun will continue to shine until in another 5,000 million years it too becomes cold. And after that? But Albritton does not indulge in such fantasies.

G.Y. Craig is Professor of Geology at the University of Edinburgh.

\section{Trap for the unwary}

\author{
William H. McNeill
}

The Fates of Nations: A Biological Theory of History. By Paul Colinvaux. Pp.383. ISBN 0-671-25204-6. (Simon and Schuster: 1980.) \$12.95 US only.

FOR the intellectual wanderer, impatient with the myopia of specialization, there are great risks in invading an unfamiliar turf. Jealous experts lie in wait for the newcomer to display his ignorance of their discipline by some slip of tongue or pen, and the complications of the new subject may not conform readily to the insights the newcomer brings from some other discipline.

This, unfortunately, is the case with Paul Colinvaux's book, The Fates of Nations. Colinvaux is an ecologist whose speciality is Ice Age Alaska and the land bridge which once allowed animals and plants to migrate from Asia to America across what is now the Bering Strait. For general readers, however, his best-known work is a summation of recent ecological niche theory which goes by the catchy title Why Big Fierce Animals are Rare (recently issued in paperback by Penguin). As an historian, who, like Colinvaux, has found it irresistible to wander across recognized disciplinary boundaries, I found this essay instructive and persuasive. But now when he takes on my own field of expertise, the human past, and seeks to illumine it by bringing ecological niche theory to bear, I find Colinvaux's ideas inadequate and his information radically defective.

As he engagingly explains at the end of the book in a "Note on Sources and Substance", he began to think about a "formal theory of history" in 1971, relying on the history "which is the common knowledge of Christendom", i.e. on what he remembered from his school days in England. This he reinforced by reading Toynbee's "overview of history's facts", and by consulting a few experts on battles - Livy, Tacitus, Arrian - as well as more modern writers like Liddell Hart and J. F. C. Fuller. He found the barrister Edward Creasy's Fifteen Decisive Battles of the World, first published in 1854, especially useful, while Field Marshal Montgomery's A History of Warfare supplied him with "the clearest insight into what gave victory in many a crucial battle"'. Thus, as Colinvaux tells us himself, his method of mastering history was studiously to disregard what professional historians have been doing since World War I to modify the patriotic and political history so ably caricatured in 1066 and All That.

With 1066 and All That plus school-boy Latin as his guide, and Toynbee as guarantor of "facts", what does an intrepid ecologist discover in the human past? The answer is a rhythm of rise and fall, predictable in the light of ecological niche theory. It may be summarized as follows. Initially, history starts when a group of human beings develops a new technique that allows them to enlarge the ecological niches in which they live. This leads to a rise in population, for human beings have always pursued a breeding strategy - the large young gambit - that requires each breeding couple to raise as many children as they think they can afford. This strategy, Colinvaux assures us, has never altered, though he does not assert that it is instinctive.

Once enlarged niche spaces start to fill up as population increases, the prospering community faces a crisis. Since growing numbers with no increase in resources will force them to accept narrower niches again, they must look abroad to find the means to sustain their heightened expectations. Trade, colonization and aggressive war, aimed at taking land away from those in possession, are the alternatives such a population faces, and this is what history is all about. Successful communities expand and create empires; but sooner or later, expansion ceases. Colinvaux is completely silent on what stops expansion. On his principles I can see no reason for the process he sketches not to continue indefinitely, until the most successful aggressor has created an empire of the Earth. But the "common knowledge of Christendom" makes clear that a limit was set somehow, and Colinvaux shows his deference to facts by stopping the expansion of the Roman Empire at the Rhine and Danube - though, as I say, he gives no reason for this interruption of a process which he has declared to be both predictable and inevitable.

Once territorial expansion stops, the continued growth of population requires narrowed niches; and narrowed niches will be accepted only reluctantly by the population concerned. This means an oppressive government - a police state in fact, in which the rich, clinging to their broad niches, impose their power on the poor by dint of "regimentation, bureaucracy, class, rationing and caste", (p. 64). Such a regime is vulnerable from without, and eventually barbarian invaders, technologically abreast of the latest methods of civilized warfare, will succeed in destroying the oppressive regime by cutting off food supplies to the cities. The newcomers institute a barbarian pattern of life in which local consumers depend on local food production. This sharply reduces the total number of inhabitants, since the urban masses, congregated under the regime of civilization into vast cities, are unable to maintain the breeding strategy that had hitherto led to an ever-mounting population. They simply die off, leaving a sparsely settled countryside to start the cycle of civilization over again. 